\title{
The Living Theatre: A Brief History of a Bodily Metaphor
}

\author{
Sarah Bay-Cheng \\ Amy Strahler Holzapfel ${ }^{1}$
}

It is a question, therefore, of making the theater, in the proper sense of the world, a function; something as localized and as precise as the circulation of the blood in the arteries. ...

\section{-Antonin Artaud, The Theatre of Cruelty (First Manifesto)}

This means that the body, as the theater, is a site, like a crypt: an apparatus designed for both protection and preservation.

\section{-Alice Rayner, Ghosts: Death's Double and the Phe- nomena of Theatre}

By now, we are nearly all familiar with the metaphor of the living theatre. The life of the drama, the stage life, the living art wend their way continuously through the criticism, theory, and practice of theatre and performance studies of the past century or more. The analogy is so entrenched in the rhetoric of theatre and performance that we hardly register the oddity of the idea. The title of the 2010 ATHE conference-Theatre Alive: Theatre, Media, Survival-provides, perhaps, the best example of late. Examined more closely, however, we find that this figuration contains a central assumption in need of further questioning: the conception of theatre itself as a living, reproducing, and dying body.

In this essay, we revisit the recent history of theatre's body to articulate the persistence of this metaphor and its deeper implications for the field of theatre and performance studies. After a century of living, dying, postliving, and rebirth, such theoretical formulations, we argue, may be limited. Theatre itself is not and has never been a living thing, nor is it a body, though it is certainly constituted by living bodies. Such metaphors obscure the ways theatrical forms have always sought to

Sarah Bay-Cheng is associate professor \& director of graduate studies in theatre at the University at Buffalo, where she teaches courses in dramatic literature, performance theory, and intermediality. Her publications include Mapping Intermediality in Performance (2010) and Mama Dada: Gertrude Stein's Avant-Garde Theater (2005), as well as various essays and reviews.

Amy Strahler Holzapfel is an assistant professor of theatre at Williams College. For the upcoming year, she will be a Lehman Fellow at the Oakley Center for Arts \& Humanities, completing her book Reality Effects: Theatre in the Dawn of a Photographic Age. 
integrate, even to colonize, other forms: texts, spectacle, music, and media. Indeed, the integration of a bodily metaphor may be less the articulation of an organic whole than a compensation for the haphazard appropriation of other art forms. In our view, the bodily metaphor serves primarily to smooth the rough contours of an art form that has, from its very origins, lacked its own prominent ontology. What's more, in comparing theatre to a living body, one necessarily individuates the art form as well as its historical contents. That is, by referring to a play or production as a living thing we bestow upon it a uniqueness, rarity, and subjectivity of its own - we make it human. There's a real danger in this: to theorize theatre as a life form or humanlike body may legitimize and reify canonical approaches to our field, since the emphasis on the life, death, rebirth, and haunting of individual plays, productions, or elements of performance may, in the worst cases, serve the interests of a myopic historical analysis. ${ }^{2}$ Instead of comparing theatre to an animate life form or body, then, we propose at the close of this essay a definition of the art form that brings us into the twenty-first century: theatre as a network.

Let us begin, however, by addressing the two quotations appearing at the start of this essay. Each offers a heuristic treatment of theatre's relation to the body: for Antonin Artaud, theatre becomes itself a bodily form; for Alice Rayner, theatre becomes an embodied "site." That is to say, in Artaud's poetry, theatre is likened to a bodily mechanism that produces physiological and psychological effects, such as arterial circulation and dreams in the brain, whereas Rayner conceives of theatre as both a body and a "crypt" that preserves and houses dead material over time. In less than a century, theatre's complex metaphoric relationship to the body moves from one focused on promoting its life-giving functions (its blood and dreams) to one devoted to safekeeping dead things. How did such a movement occur?

To consider how theatre has been theorized as a living or dying body over the past century demands that we first ask, what is a body? A body, according to Webster's Dictionary, is "the organized physical substance of an animal or plant either living or dead," as well as, "something that embodies or gives concrete reality to a thing." or that which embodies things, giving shape to "concrete reality." Several studies from the past two decades have addressed the question of how theatre functions as or in relation to bodily forms. For example, in Bodied Spaces, Stanton B. Garner, Jr. suggests, "Theatrical space is 'bodied' in the sense of being comprised of bodies positioned within a perceptual field, but it is also 'bodied' in the more fundamental sense of 'bodied forth,' oriented in terms of a body that exists not just as the object of perception but as its originating site, its zero point." ${ }^{\prime 4}$ As Garner wisely observes, Western theatre's perspective design is itself a "bodied" one, derived from the point of view of an audience member whose field of vision derives from her own living, breathing, beholding body. To discuss the relationship of the theatre to the body is, therefore, to ask in what ways the actors, spectators, theatrical space, and even 
the architecture are themselves "bodied." Garner's phenomenological analysis provides scholars with a rich vocabulary for approaching the bodied aspects of theatre practice, yet it invites deeper consideration of what we view as a significant additional line of inquiry: how the theatre itself has been theorized as a body, one that like all animal or human bodies, breathes, circulates blood, reproduces, and dies. ${ }^{5}$ This metaphorically living theatre is defined discursively not only as a site that spatially houses and presents living (or dead) bodies but also as itself a living (and dying) body.

Our inquiry is indebted to W. J. T. Mitchell's What Do Pictures Want? The Lives and Loves of Images, in which he aims "to look at the varieties of animation or vitality that are attributed to images, the agency, motivation, autonomy, aura, fecundity, or other symptoms that makes pictures into 'vital signs' by which I mean not merely signs for living things but signs as living things." "If we replace "theatre" for "images" in Mitchell's phrasing, we might recognize the familiar characterization of the theatre as a living or vital body, "driven by desire and appetites," attributed fecundity or sterility, and subject, like all bodies, to its own eventual death. Whereas Mitchell exposes a rather subtle formulation of images as living, desiring things, the deliberate casting of a living and dying theatre is often invoked to distinguish it from other art forms in contemporary discourse. As Stephen Di Benedetto neatly summarizes, "Theatre is not merely a form of visual art, but also a form of mediated, sensory stimulation, where a practitioner's compositional strategies make the stage a living, breathing organism."

Indeed, surveying the recent Western critical vernacular it is hard to find a more ubiquitous description of the theatre than as a living body, dependent upon its perpetual life status for its continued existence and relevance. Consider, for example, W. B. Worthen's assertion that a drama must be evaluated both in its original context and "in our culture, where the play continues to live," at the titles of some of the most important recent contributions to our field, such as Edwin Wilson and Alvin Goldfarb's theatre history textbook Living Theatre: A History (2000). ${ }^{9}$ Yet, the trend may also be cited in less obvious places. In his first millennial issue of TDR (2000), for example, Richard Schechner titled his editorial comment, "Theatre Alive in the New Millennium." ${ }^{10}$ Through his renunciation of his earlier oft-repeated proclamation of the "death of theatre," Schechner acknowledges that theatre had, in fact, survived into the twenty-first century. Citing artists such as Eugenio Barba, Elizabeth LeCompte, Robert Wilson, Anne Bogart, and Suzuki Tadashi as evidence of theatre's "alive"-ness, Schechner asserts that, "No matter old, new, or restored; the traditional/classic is alive alongside the popular, the commercial, and the avant-garde." ${ }^{\prime 11}$ Although the references to theatre artists included almost exclusively those whose careers began in the 1960s and 1970s, Schechner credits this unexpected endurance of theatre not to the artists but to the classical, edifying theatre itself as an evolving form. "Theatre," he writes, "has 
proven vital because it is extremely adaptable and not locked into one or another genre." ${ }^{12}$ What is striking here is not that Schechner reverses his earlier position but that he does so by defining theatre as both alive and evolving, a medium whose very adaptability has increased its chances of evolutionary "survival."

With this in mind, what past does the living and dying theatre body invoke and what future developments does it portend? What are the implications for a critical perspective that theorizes theatre as a "living organism," complete with a body that is born, reproduces, dies, and - in recent years it seems - might even return from the dead? The notion of the living theatre has evolved over the past half-century, alongside central ontological and phenomenological debates over its distinction from other forms of presumably live media, necessitating an unraveling of the distinction between theatre as "living" and theatre as "live." By briefly tracing these shifts and trends, we may uncover the past investments in theatre's history as a body and its future implications for new directions in theatre theory. At the conclusion of this review, we consider the ways in which our field has become saturated in recent decades with the metaphor of theatre as, alternately, a reproductive body, a "surrogate," a "ghost" (and occasionally all three) made up of, in Roland Barthes's terminology, a "tissue of quotations." "13 Our essay thus builds to a consideration of how theatre has begun to be articulated in contemporary theoretical discourse as a body caught in the throes of an afterlife, a body whose future emerges in the wake of its own demise.

\section{The Living Theatre?}

In some ways, it makes sense to start at the end. Or, put another way, to talk of the theatre's life, one must confront its potential death. As Mitchell notes, definitions of life become rather sticky, thus demanding the simplest formulation: "a living thing is something that can die."14 It should come as no surprise, then, that much of theatre's alleged life or vitality seems to stem from its perpetually threatened demise and exhaustive list of near-fatalities over time. ${ }^{15}$ A quick glance through Jonas Barish's much-cited tome The Anti-Theatrical Prejudice (1985) reveals an impressive lineage of attacks and death-threats against the theatre launched, in his words, "Not only by straight-laced moralists but by major philosophers-Plato, Saint Augustine, Rousseau, Nietzsche." Barish asks, "Does their hostility toward the theatre point to a fundamental human failing?"16 Barish's query invites two, and no doubt many more, interpretations: either the "human failing" he gestures toward belongs to those of us who participate in either upholding or debasing the form, or, viewed another way, the "human failing" belongs to the agency of theatre itself. In other words, is there something about the theatre that is, like ourselves, strikingly "human" and therefore, perhaps, doomed to experience a fall?

Though antitheatrical sentiment may be traced throughout the historical record, it is primarily in the context of the modern period, we conjecture, that the 
metaphor of theatre to a living body under perpetual threat becomes particularly prevalent in the field. Martin Puchner situates modernism's antitheatricality as directed, in part, against the physiological body of the actor, noting that, "The violence of symbolism's polemic against the presence of the actor onstage is perhaps nowhere as stark as in the writings of Edward Gordon Craig." ${ }^{17}$ And yet, somewhat paradoxically, the shift to theorizing theatre not as "sign for living things" but "sign as living thing" first emerged in modernism through the theories of not only Craig, but also his fellow antitheatrical technologist, Adolphe Appia. Both Craig and Appia approached the institution of theatre, including its structure, drama, people, and performances, as a composite living body, an organism to be studied and constructed as a mechanical system, albeit one purged of the unique physiology and individuality of human performers. As designers, they often discarded the singular, flawed body of the actor in favor of the theatre's own utopian collective body. Craig notoriously saw puppets as the ideal actors specifically because they are free of "the weakness and tremors of the flesh."18 But even in the midst of such antiphysiological sentiment, we see the emergence of a discursive metaphorical shift that, perhaps only rhetorically, begins to gesture toward the idea of the theatre itself as a living body. Craig's A Living Theatre (1913), for example, and Adolphe Appia's A Work of Living Art: A Theory of the Theatre (1927) both cite the theatre as a living organism that may be defined less as the composite art of Wagner's Gesamtkunstwerk than as the integrated system of a biomechanical body. Appia even went so far as to include and even unite the bodies of both the spectators and the actors within his "organic" theatre body. As he writes in "Organic Unity" (1921), "We are the play and the stage, because it is our living body that creates them. Dramatic art is a spontaneous creation of the body; our body is the dramatic author." 19 Throughout this and other writings, Appia often conflated the theatre with the body, comparing, for instance, the space within the human body to the space in the theatre: "It is not merely mechanically that we possess Space and are its centre: it is because we are living. Space is our life; our life creates Space; our body expresses it." ${ }^{20}$ Appia's notions of the body refer to neither a single person (such as an individual actor or spectator), nor a single place, but rather suggest a figural composition encompassing a range of bodies and spaces.

For his part, Craig sought to articulate a theatrical body as both an ideal and a methodology. The cover illustration for A Living Theatre provided his own diagram of the human form, mathematically constructed in the model of Leonardo da Vinci's Vitruvian Man. Returning to a Descartes diagrammatic, Craig himself argued (in reference to the Russian Ballet) that the essence of art was a mechanical body separate from the bodies of the viewers: "Its perfection is physical. Its appeal is to our senses, not through them." ${ }^{21}$ In nearly all of his theoretical writings about performance, Craig attempted to usurp the bodily authority of the actors into the theatre itself, by replacing the individual human bodies with a mechanized, living 
theatre body. For all of Craig's attacks on the biological systems and physiology of actors displaying the "weakness and tremors of the flesh," Craig retained and reworked the bodily metaphor. ${ }^{22}$

Tim Armstrong has demonstrated in his Modernism, Technology, and the Body (1998) the ways in which technology transformed conceptions of the modern living body from a purely organic and animalistic self into a hybrid of mechanical and biological systems: "At the beginning of the century," he writes, "the body was the machine in which the self lived; the site of an animal nature which required conscious regulation. ${ }^{\prime 23}$ Tracing the evolution of emerging medical technologies in the late nineteenth century, Armstrong considers the ways in which, "The body was resolved into a complex of different biomechanical systems, conceived in thermodynamic terms. Other technologies were applied to it: drugs, inoculation, electricity; as well as various external regimes designed to improve its make-up, shape, and the flow of energies through it." ${ }^{24}$ This, it seems, was the modern body that Craig and Appia invoked when they described a living theatre no longer reliant on individual actor-bodies, but composed as a series of mechanical, physicalized systems. Theatre's hybridity of lifelike elements and mechanical systems, therefore, fits within this new, modernist conception of the body, one perhaps most strikingly represented in the protocyborgs of Karel Capek's R.U.R. (written 1920, produced 1921). The modernist living theatre was, thus, a complicated structure, whose very bodily-mechanical intricacies and functions granted it vitality. Even as late as the 1940s, designer Robert Edmond Jones would note in The Dramatic Imagination (1941), "A drama is not an engine, running at full speed from the overture to the final curtain, but a living organism." ${ }^{25}$ But Jones's own defense of the drama as a "living organism" is bound to a defense against modernism's own antiphysiological skepticism of the human, corporeal body of the actor, whose functions cannot be properly regulated or maintained.

This hybrid theatre-body of the modern technologists was subsequently exploited and impossibly extended by Artaud in "No More Masterpieces" when he proposed that "the encounter upon the stage of two passionate manifestations, two living centers, two nervous magnetisms is something as entire, true, even decisive, as, in life the encounter of one epidermis with another in timeless debauchery." ${ }^{26}$ In such a context, it appears that theatre emerges (is born?) from an act of bodily intercourse. For all of his ambivalence toward bodies (including his own), Artaud repeatedly conflates his ideal conception of the theatre with bodily senses, blurring the line between the theatre as it occurs in time and the bodily limits of its spectators. His theories of theatre as a kind of (perverse) body follow, however, the antitheatrical modernists' ambivalence to performing flesh, again seeking to extend the metaphor of the body from a single being into a larger inhabitable space, what he elsewhere called "an over-heated factory." ${ }^{27}$ It was from Artaud that Gilles Deleuze and Félix Guattari took their "body without organs," based on Artaud's 1947 radio play, "To 
Have Done with the Judgment of God" in which the body's freedom is its literal undoing: "When you will have made him a body without organs, then you will have delivered him from all his automatic reactions and restored him to his true freedom." ${ }^{28}$ As mutually assured sites of destruction, the theatre and its bodies would become the new stages for the performance of technological realization. For Artaud, the living theatre, like the living body, was potent primarily in that it could be contaminated and made to suffer, thereby transforming itself through suffering. As such, Artaud became and would remain a crucial touchstone for the metaphor of the living theatre in the latter half of the twentieth century, realized often in the images of suffering, struggling bodies.

Given Artaud's extended discourse of pain and suffering, it is unsurprising that his writings would become particularly influential in the postwar years. In theatre centers throughout Europe and North America, the fallout from the atrocities of World War II and the Holocaust made the affirmation of life central to theatre theory of the 1950s and 1960s. In an interview conducted in 1963, for example, Roger Blin discusses his productions of Genet's dramas as an art of a living theatre in which the props, décor, and all material elements become analogous to living beings:

Take a telephone, for example. Place it on a table on stage. That's all right. But I want that telephone to be able to eat, to talk, to have a life of its own. It must be an animate object. The prop must be a composite of what you see and what you have seen. The décor must be alive, move and breathe. It must be human. ${ }^{29}$

In a world in which so much had been dehumanized, perhaps the only answer was to rehumanize all aspects of the stage. For Blin, at least, the art of Genet and Beckett offered a timely and forceful alternative to what he later called the "stupid realism" of the popular theatre. Here, the objectivity of perception becomes aligned with death, whereas subjectivity reinforces the living and human qualities of theatre. The post-Einsteinian shift to relativism of perspective surely influenced Blin's definition of "total realism," yet viewed in the aftermath of two World Wars the above citation invites an ideological interpretation as well. Perceiving the set as an entity that can "move and breathe," as Blin implies, is itself a liberating action by which "all restrictions [may be] broken." ${ }^{30}$ It's not surprising, then, that the solipsism of the postwar theatre and its evocation of its own components (its telephones, its settings) as "alive" or "human" leads straight into the radical culture of the 1960s, with its strong emphasis on the living, bodily dimensions of theatre as one of its most powerful political tools.

Not content to be merely a passive picture, image, or other visual representation of life, theatre itself begins in the postwar period to take on the characteristics, features, attributes, and agency of a living, reproducing, and dying body. Alongside 
this conceptual shift may be found, perhaps, a political urgency informing this theoretical design; as Elizabeth Grosz claims in Volatile Bodies (1994), "Far from being an inert, passive, non-cultural and ahistorical term, the body may be seen as the crucial term, the site of contestation, in a series of economic, political, sexual and intellectual struggles. ${ }^{\text {31 }}$ Revived in postwar theoretical discourse as a living body, theatre becomes a figural terrain ripped apart through purposeful acts of sparagmos inflicted upon it by those attempting to challenge its vitality. As HansThies Lehmann speculates, "It was not least of all the idea of an analogy of the work of art and a living organic body that motivated the vehement conservative resistance against modernism's propensity for deconstruction and montage," as if the attack on the integrated form of art were itself an attack upon the human being. ${ }^{32}$

Most famously, Judith Malina and Julian Beck founded their post-Artaudian collective ensemble as The Living Theatre in 1949, and Beck later titled his autobiography The Life of the Theatre (1972), appearing in the title, at least, to cast his own life as the life of the theatre itself. Even a cursory glance at titles emerging from this epoch reveals a prominent preoccupation with the appendages of theatre as concomitant parts of its living body: Alan S. Downer's “The Life of Our Design" (1949); Elmer Rice's The Living Theatre (1959); Eric Bentley's The Life of the Drama (1964); and Peter Brook's essay, "The Play is the Message" (1965). In his iconic formulation Brook argues, "First we should try to rediscover the play as a living thing; then we shall be able to analyze our discoveries." ${ }^{\prime 33}$ This trend emphasizing theatre's liveliness or living thing-ness appeared in several iterations including those that emphasized the living qualities of both actors and audience, such as Robert Brustein's praise for The Living Theatre's 1959 production of Pirandello's Tonight We Improvise with "its unique understanding that there can be no living theatre without a living audience. ${ }^{\prime 34}$ Such criticism perpetuated the critical sense of theatre itself as an almost autonomous living entity and reinforced considerations of individual plays, productions, and even theatre buildings themselves as part of the living body of theatre.

By the mid-1960s, however, the life of the theatre appeared tenuous again, and by the 1970s, theatre theory turned decidedly more deadly. Artaud had coupled his life of the theatre with a deathly double, but theatre theory throughout the 1970s and 1980s felt compelled to ask more explicitly, "Is theatre really dead?" In his 1982 book, Blooded Thought: Occasions for Theatre, director and theorist Herbert Blau returned to Artaud's comparison between theatre and the body, with continued emphasis on the theatre's vulnerable mortality, poised perpetually on the edge of death: "When the blood occludes in a vein, you may die; when the bleeding occludes in a wound, you may live. Concerned as it has been with living and dying, there is something occluded in the theatre that is not conclusive. ${ }^{{ }^{35}} \mathrm{In}$ such phrasing, the theatre seemed to reaffirm its status as a living thing by becoming an even more vulnerable body, capable of living, bleeding, and dying. Blau, thus, 
returned to Artaud's conflation of theatre and physical vulnerability, noting that it was the indeterminate life status of the theatre that made it particularly vital. ${ }^{36}$ We watch the theatre, not knowing if it is going to live or die; this very tension is what allows it to survive. ${ }^{37}$

Modernist conceptions of a living theatre, therefore, gave way to postmodern fascinations with the swan song of a dying theatre. If modernism ushered in an era of theatrical life, the postmodern theatre appeared to be ready to accept its last rites. Perhaps following the poststructuralist "death of the author," alongside the "death of meaning," "death of language," and "death of culture," theatrical theory gravitated toward theatre's indeterminate status between life and death, its liminal phase. Blau repeatedly focused upon the death-potential not of the theatre per se but of its participants: "The fact that he who is performing can die there in front of your eyes; is in fact doing so. Of all the performing arts, the theatre stinks most of mortality." 38 And, again in Blooded Thought: "It is the actor's mortality which is the acted subject, for he is right there dying in front of your eyes." ${ }^{39}$ Blau's vision of a theatre inhabited by dying (as opposed to living) performers was repeated by theatre artists elsewhere, as in Heiner Müller's description of theatre as the spectacle of the "potentially dying person," ${ }^{40}$ and in the more recent writings of Howard Barker, who suggests that, "Since theatre ceased to make death its subject it surrendered its authority over the human soul." ${ }^{41}$ While these perspectives focused primarily on the theatre as a site inhabited by dying bodies, rather than as a dying body itself, they, nevertheless, paved a course for other studies, which conceived of the myriad ways in which the once living components of theatre-its plays, characters, settings, actors, audiences-were nearing their end. George Steiner's The Death of Tragedy (1996) considered, for example, the demise of genre as a defining principle of theatrical form, and Elinor Fuch's Death of Character (1996) theorized the postmodern theatre as the endpoint of an eclipse in character underway for nearly a century. ${ }^{42}$

\section{The Live Theatre}

While such examples may on the surface suggest a definition of theatre as an artistic medium comprised of living participants (rather than a life form in and of itself), they quickly led to more conscious attempts in the mid-1980s and 1990s to articulate theatre's "liveness" as distinct from other forms of performance and spectacle. Theatre's earlier discussions of a living and dying body shifted toward debates centered on theatre's liveness, a term used in both modernist and postmodern criticism, particularly in the wake of early recording technology. Not coincidentally, the mortal bodies (i.e., actors, either living or dying) that had been the lifeline of theatre throughout the twentieth century appear to be nearing not so much death as obsolescence. Theorists who have noted this shift in theatre point to the echo or reverberation of the living theatre in the 1990s. Philip Auslander, for example, 
begins his argument in Liveness (1999) by critiquing Peggy Phelan's assertion that "[p]erformance's only life is in the present," ${ }^{43}$ a sentiment that attempted, in part, to return theatre, and indeed all of performance, to its living origins, as well as reaffirming its ontological status as a living thing. Against Phelan's privileging of performance's ontological life, Auslander argues, "[H]istorically, the live is actually an effect of mediatization, not the other way around." ${ }^{\prime 4}$ In a related essay published a few years later, "Live from Cyberspace" (2002), Auslander expanded this argument by arguing, "[T]he concept of the live was articulated in relation to technological change. Recording technology brought the live into being, but under conditions that permitted a clear distinction between the existing mode of performance and the new one." ${ }^{45}$ This essay considered the performance of virtual "Internet chatterbots" as a challenge to existing definitions of live performance. Contending that the chatterbot performances were "live," if not also "a-live," Auslander concluded that the chatterbot "undermines the idea that live performance is a specifically human activity; it subverts the centrality of the live, organic presence of human beings to the experience of live performance; and it casts into doubt the existential significance attributed to live performance. ${ }^{.46}$ Although Auslander acknowledges that the chatterbot is incapable of death and dying in the same manner as a living body on stage, he ultimately declares this distinction irrelevant. If the chatterbot can perform "live" by any number of definitions, who cares if it cannot die? The late twentieth-century living theatre thus confronted what Steve Dixon and Barry Smith termed "the liveness problem," a fundamental threat to the very notion of a living theatre as that which ontologically set theatre apart from other forms of media. ${ }^{47}$ Almost instantly, the question of theatre's life seemed to be replaced by concern over its liveness, a quality no longer related to flesh and blood physicality but instead conditioned by and reliant on media technologies for its survival into the new millennium. As Auslander demonstrates in his analysis of chatterbots, "[W]e can see that liveness is first and foremost a temporal relationship, a relationship of simultaneity. ... The ability to present performances that can be watched as they occur, or, to switch to a technological vocabulary, to perform in real time - the heart of the concept of liveness - is an ability shared by human beings and chatterbots." ${ }^{18}$

It is worth noting here that the focus turned from living theatre to liveness at almost precisely the same moment that drama became postdramatic and humanism became posthuman: Auslander's Liveness, N. Katherine Hayles's How We Became Posthuman (1999), and Lehmann's The Postdramatic Theater (published in an abbreviated English version in 2006), all noted a late twentieth-century epistemological shift that Lehmann termed "the caesura of media society." ${ }^{49}$ Among the many significant contributions from all three books was their reformulation of the performing body as one that exists beyond the binaries of living/dead or live/ un-live.

While Auslander challenged the very notion of a "live" theatre by attacking 
the ontology of liveness, Hayles argued that, although the posthuman "is likely to be seen as antihuman," one need not cast these terms in binary opposition. According to Hayles, "The posthuman subject is an amalgam, a collection of heterogeneous components, a material-informational entity whose boundaries undergo continuous construction and reconstruction." ${ }^{50}$ The posthuman, therefore, reflects our experience of living in a world without clear ontological distinctions, or as Ralf Remshardt puts it, "[P]osthumanism dispenses with the categorical separation of 'body and world' or 'self and other' that constituted an older model of performance premised on presence." ${ }^{, 1}$ For his part, Lehmann identifies a shift from the modernist dramatic process "between the bodies" to a "postdramatic process [that] occurs with/on/to the body." Moreover, Lehmann argues that the postdramatic body is often created as "the image of its agony." ${ }^{52}$ Without getting rid of the performing body, then, all three theorists recontextualize the "postdramatic body" in light of media technology (Lehmann called it a "technically infiltrated body"), although the body's ability to die remained its primary avenue of resistance to the technological hegemony.

Pursuing Lehmann's argument further, we note that he attempts to outline the significance of the vulnerable physical body even as its very corporeality appears to be usurped by technology. For Lehmann, like the body-death theorists before him, the theatre's liveness depends upon its potential death as that which distinguishes it from all other mediated forms: "In media communication technology the hiatus of mathematization separates the subjects from each other, so that their proximity and distance become irrelevant. The theatre, however, consisting of a shared timespace of mortality, articulates as a performative act the necessity of engaging with death, i.e., with the (a)liveness of life." ${ }^{\prime 53}$ It is the constant and habitual death-threat of media, then, that accentuates the very "liveness" of theatre, even as the theatre itself, as an intermedial body, incorporates other forms of media and their theories into performance.

\section{Theatre's Afterlife?}

Just as the semantics of "post-" created a problem to describe what came after it (post-post?), theatre studies needed new language to describe the postliving, postlive theatre. From bodily metaphors, theatre and performance studies thus branched out into new metaphors of the afterlife. These new metaphors have taken two major directions: ghosts and genetics. If for Artaud the modern theatre was akin to a living, flesh and blood body, and for Auslander the postmodern theatre was defined in relation to liveness, theatre in the early twenty-first century apparently exists as something haunted by its former incarnations, a return or recycling of dead forms reanimated by the physicality of the living. Joseph Roach's Cities of the Dead (1996), perhaps, first suggests this kind of ghosting when he conceives of performance, theatrical and otherwise, as a process of "surrogation" by which 
"the dead may speak freely now only through the bodies of the living." 54 In his more recent It (2005), he describes actors as "living effigies" of the dead. ${ }^{55}$ Roach's argument relates to a recent and growing collection of postliving (or haunting) studies, such as Marvin Carlson's The Haunted Stage (2000), Andrew Sofer's The Stage Life of Props (2003), Diana Taylor's The Archive and the Repertoire: Performing Cultural Memory in the Americas (2003), and Alice Rayner's Ghosts: Death's Double and the Phenomenon of Theatre (2006). Does the emphasis on theater as a post-animate or ghostly form simply represent the latest example in a long line of articulations of theatre as sign "as living thing" or does it represent a departure or break from the historical record?

At the 2008 ASTR conference in Boston, Roach summarized the culture of theatre as that which offers to its participants the "tantalizing availability of a second life," ${ }^{\circ 6}$ perhaps unintentionally invoking the multiplayer online world, Second Life. Viewed within the timeline of theatre's theoretical development from life to liveness to impending death, the emergence of theatre's second life, like the virtual world of the same name, seems to fulfill the vision of so much science fiction; that faced with the impending death of the body another virtual space will appear into which consciousness may escape. ${ }^{57}$ This escape, often characterized as reanimation, reappearance and timelessness ${ }^{58}$ as well as the durability of data-paradoxically fragile and unstable, yet nearly impossible to fully erase-becomes central to recent discussions of theatre as a haunted being, or ghost. More than a reference to a specific virtual environment, Roach's second life points to recent conceptions of theatre and performance in its postdeath state as an eternally recurring afterlife. In her theorization of theatre's ghosting, Alice Rayner offers a reading of what she terms the "theater-body" that contextualizes theatre both as an event in the moment and a bodily container for all prior moments:

The phenomenal appearance of the body is . . . an encrypted space that, theaterlike, is haunted by the history of its own selfrepresentation as well as the history of others who inhabit it. The body/theater is thus an exterior space that displays like hollow vessel or vaulted crypt, the surfaces of its own interiority. ${ }^{59}$

Rayner clearly describes both theatre and its function as historical agent as a body, emptied and waiting for the reanimation of the historical ghost. Such a conception is similar to Marvin Carlson's argument in Haunted Stage that the theatre experience is cumulative. The theatre, like the data continually added to virtual environments, continues to map onto itself new experiences and events of all iterations.

On the one hand, then, the concept of ghosting may be seen to refer to the way theatre, in Carlson's words, "uses the memory of previous encounters to understand and interpret encounters with new and somewhat different but apparently similar 
phenomena." ${ }^{60}$ In Carlson's materialist analysis, the theatre's accouterments, its actual physical "things" that "appear again tonight at the performance" become the indispensable gear of haunting. ${ }^{61}$ Similarly, in The Stage Life of Props (2003), Andrew Sofer considers the material histories of properties as, in a sense, living things, or at least things that maintain their own lives: "What do we mean," he asks, "when we say that an inanimate object 'takes on a life of its own' in performance?"62 As he readily admits, the use of the metaphor is somewhat misleading, as the stage life comes not from the prop's own liveliness, but rather from its function within the drama. In fact, according to Sofer, it is the prop that feeds the life of the drama itself and is, again, cast in bodily terms. The defamiliarization of a prop, for example, does not "paralyze" the drama, but "reinvigorates it."

Sofer's study reviews the ways theatre performances deploy key objects in their respective dramas, concluding that "the function of the stage property duplicates that of the theater itself: to bring dead images back to life... . Our pleasure in seeing the relic revived, the dead metaphor is made to speak again, is the very reason we go to the theater to see a play we already know well." ${ }^{64}$ Despite these references, however, Sofer makes it clear that his emphasis is on "the stage life of props," not the stage life of props. He carefully unpacks the metaphor for its application of objects to their role on the stage, yet, as for so many theatre scholars of the last twenty years, the metaphor of the theatre as life form haunts the theatrical background of his analysis. What such ghostly studies collectively suggest is the possibility that the seemingly dead, living theatre may be merely dormant. Such a theatre can, thus, never die as long as its ghostly essence finds new bodies to inhabit.

As a body, theatre is haunted not only by ghosts, but also by its own genetic, biological lineage. Following, in part, from Roach's "genealogies of performance," itself based on Foucault's theorizations of historical genealogies, the phrase "genetics of performance" suggests that performance possesses heredity and a genealogical record that can be traced by historians in the manner of documenting a family tree, one that organically evolves (and also, to return to Schechner, adapts) over time. Emphasis on the genetic aspects of theatre can be found in journals such as Theatre Research International, which recently published a special issue titled "The Genetics of Performance" (2008). In this issue, Josette Féral introduces the analytical possibilities of genetic theory in application to theatre and performance, stressing the ways such methodology can promote a focus on "the question of creation" rather than "an obsession with the final text." ${ }^{95}$ In describing the process of a genetic study of performance, Féral observes how "such an analysis would attempt to shed light on how a given scene or gesture was born; under what circumstances it was created; and how changes in the practitioner's approach, corrections in their direction and variations in their focus come into play." ${ }^{966}$

Can we, however, map the genetic history of our performance lineage, one wonders, in the manner in which scientists have mapped the human genome? In 
defending such an approach, Jean-Marie Thomasseau writes of the project: "On the whole, the ultimate objective of a genetic non-contemporary theatrical study would be, first and foremost, to bring the plastic treatment of the dialogued text to light by following the incessant flux of the different functional writings in the movement and the process of gestation. ${ }^{967}$ In this analogy, the production of theatre is viewed not only as a genetic form but also as a reproductive body itself, developed via a period of "gestation." Linking "the method of the theatre geneticist to that of the historian," Thomasseau proposes a method of classification of theatre based on the "four major stages of non-contemporary theatrical creation: the writing of the text, the rehearsals, the performances, and, finally, the revivals." ${ }^{\circ 8}$

While the methodology of classification itself is not confronted by the author, he does conclude that the historian must always be sure to "situate the "cybernetic machine' of the theatre within the incessant movement of a continual genesis." ${ }^{99}$ In other words, the difficulty of the theatre geneticist approaching the theatre's genealogical history is portrayed like that of the marine biologist conducting a history of the sea: to attempt a stable interpretation of a work that is in a state of perpetual, dynamic flux. Most striking, however, is the assumption that a genetic interpretation of theatre history, a form of classification of the historical theatrical archive, is even possible based on a retracing or mapping of lineage and, presumably, all number of impersonations and "surrogations" throughout its family history. Rayner views these genealogies as perceivable through something akin to family typologies: "Like the human body, the empty space of theater is ghosted by its own history, by its family resemblances, by subjectivity and perception. ${ }^{170}$

While genetic treatments of theatre are becoming more common, so too are genetic interpretations of performance and cultural memory at large, of course. In her reading of performance in the Americas, Diana Taylor theorizes a distinction between the archive and the repertoire in ways that suggest a further deepening of genetic analysis applied to embodied experience. In her discussion of the performances of the children of the disappeared (H.I.J.O.S.) in Argentina, for example, Taylor considers how the transmission of traumatic memory and political commitment transcends periodization through the power of performances derived from its familial and cultural inheritance: "Just as the generations share genetic materials, which these groups have actively traced through DNA testing, there are performance strategies (DNA of performance) that link their forms of activism." ${ }^{71}$ Viewing DNA itself as a "biological archive ... storing and transmitting the codes that mark the specificity of our existence as both a species and as individuals," Taylor defines the DNA of performance as a "representational practice of linking the scientific and performatic claim." ${ }^{72}$ In Taylor's theorization, performance (the repertoire) becomes analogous to an immortality created in and through performing bodies that stands counter to the mortal body of the theatre (the archive). Indeed, such conceptions of the genealogic repertoire become enduring records 
of performance.

Linking Taylor explicitly to Roach and Carlson, David Román notes in his "Archival Drag; or, the Afterlife of Performance," that performance "constitutes an embodied archival practice, whether it houses the body's own experience of itself, the rituals of Asian American cultural resilience, or an alternative genealogy of Latino belonging." He, thus, seeks to reconcile Taylor's opposition to the archive by recovering it through the body's performance as "an embodied archival practice." Whatever the emphasis, the new bodily metaphors of theatre and performance are based on endurance, on their ability to describe a theatre perpetually reincarnated perhaps, in part, because of its historical vulnerability to attack. In other words, the emphasis on afterlife, on reincarnation, on ghosting, offers the latest foolproof defense against the still ongoing antitheatrical attacks of modernism. The metaphor of the theatre as an historical, ghosted body lends itself to the living histories of genealogy, to Roach's description of actors as "living effigies," to the "family resemblances" that Rayner highlights, and, finally, to the embodied performance archive that Román outlines. It's almost as if, from a metatheatrical perspective, theatre and performance theorists have circumvented the historical lineage of antitheatrical prejudice. In essence, we've written our own deeply theatrical dramatization that scripts the theatre itself as a flesh and blood protagonist, complete with a living and dying body, cast in its own legendary passion-play that chronicles its birth, death, and return, performing its own genealogy and memories in order, in the last analysis, to preserve itself.

Or is this script more accurately a gothic romance? There is a darker side to the immortal theatre body and its afterlife. Like the horror films in which the desire to revive the dead do not bring back the deceased loved one, but rather a perverted version of the original, so too do theatre scholars fear the "lifeless" reincarnation of the dead, what Worthen calls "the zombie theory of drama," the stiffly animated, but bloodless return of the dead..$^{74}$ Rayner, too, warns, "Simply to reproduce an event, that is, to do the same play night after night, is the certain death of theatre, and to the extent that any given theatrical event is a given play, that death occurs as deadliness, as a kind of vampire or the living dead. And it bores to death." ${ }^{75}$ Theatre and performance studies, therefore, reach a kind of Frankensteinian ambivalence: a desire to revive the dead, coupled with a simultaneous fear of what ugliness that reincarnation might unleash. The solution, it seems, takes us full circle to the beginning of theatre's lifecycle (if you'll forgive us); theatre must be born again in new bodies, not simply new flesh but lived as if for the first time. "In theatre," Rayner suggests, "the recovery of writing through the voice of the performer gives a second life to the memory buried in the text."

\section{Postmortem?}

Looking over the discourse of the past century, theatre's conceptualization of 
itself as a body has evolved from positioning it as "sign for living things" to "sign as living thing" to "sign reliving things." What can we make of this evolution, from a living theatre to liveness to afterlife? Here, we are reminded of Philip K. Dick's short story "The Preserving Machine" (1969), in which a musician, concerned that his compositions will one day become lost or obsolete, transforms them via a machine into "living creatures," birds and insects which he sets free, only to find his task a failure when he attempts one day to restore his originals. The original compositions have, over the course of their lives, mutated and transformed into unrecognizable sounds. The attempt to preserve ideas as bodies is rendered not only as futile, but, more poignantly, as the very tool of historical contamination and undoing. In this, Dick seems to return us to Craig's central problem: ideas reliant on corporality endure over time neither as bodies nor as art.

Why, then, do ideas always need to be turned into bodies, whether living, dying, or re-lived? Do art forms only derive meaning if they exist in corporeal animal or human-like states? Our primary objective here has been to trace the ways in which bodily metaphors of the living theatre saturate twentieth-century theatre and performance theory. If such a review of the "living theatre" has any significance, perhaps it is simply to suggest that for the theatre to have a social, cultural, and aesthetic defense against the mechanized and technological media of the twentieth century, it first must be turned into an organic body, that is, a mortal life form. The transformation of theatrical art into bodies destined to die may be the only way to preserve itself for the future. But we must also conclude that, reviewed in totality, such perspectives are little more than rhetorical obfuscations, barriers to a more fully theorized notion of theatre as something other than metaphor. The more theatre studies clings to the notion of a body as a potential but ultimately false unifying principle, the more the field undermines its ability to examine new directions for theatre moving into the future. As we pivot into the twenty-first century, we propose it is time to let go of the living, dying, dead, undead, and reborn theatre metaphors. Theatre is always the process of connecting systems, not the unified (however briefly constituted) form of those systems. The ephemerality of theatre and performance need not be viewed as temporary lives or rebirths of ethereal theatrical essence, but as temporal processes that are dynamic and inherently unstable. If we leave behind the bodily metaphors of the twentieth century perhaps we can acknowledge that the dominant metaphor of the early twenty-first century has much in common with theatre and performance history. Theatre is not, after all, a living or dying body; theatre is a network. This distinction is significant because while bodies (arguably networks unto themselves) evolve in unconscious relation to their environments and each other, networks reveal more conspicuous constructions, deliberate connections, and explicit divisions.

Approaching theatre as a network thus allows us to view our art form as an inanimate and inscrutable, yet constructed system of communication, a web that 
can bridge, divide or intersect both discrete and overlapping times and spaces. This idea has several advantages: first, one is less likely to place too much weight upon any one individual play, production, or performance from the historical record as representative of the medium as an organic whole. Second, new methods of historical analysis open up that offer alternatives to canonical studies, such as quantitative analyses of theatre markets, trade routes, or genres. Last, viewing theatre as a network may release us from the retrograde binaries of "live" and "mediated," "organic" and "mechanical," "alive" and "dead," that have come to dominate the way we talk about our field. To truly alter these traditional oppositions, perhaps its time we consider new methods of critical inquiry rather than simply changing the contents of our analyses. Or, to put it another way, let us consider theatre as something more than the sum of its bodily parts.

\section{Notes}

1. The authors wish to thank Stanton B. Garner, Jr., Elinor Fuchs, and Robin Bernstein, as well as their two anonymous peer reviewers for their editorial responses to this essay.

2. Roland Barthes made a similar argument regarding literature, claiming that in order to circumvent the canon one must abolish the individual case study from literary history and turn to new, more quantitative methods of analysis.

3. Merriam-Webster, Inc., Webster's Ninth New Collegiate Dictionary. (Springfield, Mass.: Merriam-Webster, 1983) 164-5.

4. Stanton B. Garner, Jr., Bodied Spaces: Phenomenology and Performance in Contemporary Drama (Ithaca, NY: Cornell UP, 1994) 4.

5. 1.

6. W. J. Thomas Mitchell, What Do Pictures Want?: The Lives and Loves of Images (Chicago: U of Chicago P, 2005) 6.

7. Although critics often seek to distinguish theatre as a uniquely living body, this does not ignore the threatened death of other arts (e.g., the novel). See Stephen Di Benedetto, "Sensing Bodies: a Phenomenological Approach to the Performance Sensorium," Performance Research 8.2 (June 2003): 101.

8. W. B. Worthen, The Wadsworth Anthology of Drama, 5th ed. (Boston: Thomson Wadsworth, 2007) xi.

9. This is the current incarnation of the textbook, originally published as Living Theatre: An Introduction to Theatre History in 1982.

10. Richard Schechner, "TDR Comment: Theatre Alive in the New Millenium," TDR: The Drama Review 44.1 (2000): 5.

11. 5 .

12. 6 .

13. Roland Barthes, Image, Music, Text, trans. Stephen Heath (New York: Noonday, 1988) 146. See also, Marvin Carlson, The Haunted Stage: Theatre as Memory Machine (Ann Arbor: U of Michigan P, 2003) 5.

14. Mitchell, What Do Pictures Want?: The Lives and Loves of Images 52.

15. This characterization is not unique to theatre. See, for example, Kevin J. H. Dettmar's Is Rock Dead? (New York: Routledge, 2005). Life and death studies in theatre do appear, however, to have a much longer and more robust critical discourse than other related fields, a distinction that becomes less salient when one notes the intersection among theatre, performance studies, and the phenomenon of live performed and recorded music as noted in Philip Auslander's Liveness (1999).

16. Jonas Barish, The Anti-Theatrical Prejudice (Berkeley: U of California P, 1981): this quotation appears on the book's cover.

17. Martin Puchner, Stage Fright: Modernism, Anti-Theatricality, and Drama (Baltimore: Johns Hopkins UP, 2002) 127. 
18. Edward Gordon Craig, On the Art of the Theatre (Chicago: Browne's Bookstore, 1912) 48.

19. Adolphe Appia, "The Work of Living Art": A Theory of the Theatre, trans. H.D. Albright (Miami: U of Miami P, 1960) 40.

20. 40.

21. Qtd. in Christopher Innes, Edward Gordon Craig (Cambridge: Cambridge UP, 1983) 114.

22. Craig, On the Art of the Theatre 48.

23. Tim Armstrong, Modernism, Technology, and the Body: A Cultural Study (Cambridge: Cambridge UP, 2008) 2.

24. 4.

25. Robert Edmond Jones, The Dramatic Imagination (New York: Theatre Arts Books, 1941) 113.

26. Antonin Artaud, The Theater and Its Double, trans. Mary C. Richards, (New York: Grove, 1958) 79.

27. Antonin Artaud, "Van Gogh, the Man Suicided by Society," Artaud Anthology, ed. Jack Hirschman (San Francisco: City Lights, 1965) 158.

28. Antonin Artaud, Antonin Artaud: Selected Writings, ed. Susan Sontag (Berkeley: U of California P, 1988) 571.

29. Bettina Knapp, "Interview with Roger Blin,” Tulane Drama Review 7.3 (1963): 112.

30. 112.

31. Elizabeth Grosz, Volatile Bodies: Toward a Corporeal Feminism (Bloomington: Indiana UP, 1994) 19.

32. Hans-Thies Lehmann, The Postdramatic Theatre, trans. Karen Jürs-Munby (New York: Routledge, 2006) 88.

33. Peter Brook, "The Play is the Message," The Shifting Point: Theatre, Film and Opera, 1946-1987 (New York: Theatre Communications Group, 1994) 97.

34. Robert Brustein, Seasons of Discontent: Dramatic Opinions, 1959-1965 (New York: Simon \& Schuster, 1965) 33.

35. Herbert Blau, Blooded Thought: Occasions of Theatre (New York: Performing Arts Journal, 1982) xiii.

36. One notes, too, that in 1982 AIDS was emerging in America's urban centers, prompting a new awareness of "the plague" and disproportionately affecting the theatre as well.

37. Rebecca Schneider notes the irony of the trend, observing that, "Within a culture which privileges object remains as indices of and survivors of death, to produce such a panoply of deaths may be the only way to insure Remains in the wake of modernity's crises of authority, identity, and object. Killing the author, or sacrificing his station, may be, ironically, the means of insuring that he remains" (“Archives: Performance Remains," Performance Research 6.2 (2001): 100-8; 105.

38. Herbert Blau, "Seeming, Seeming: The Disappearing Act," The Drama Review 20.4 (December 1976): 8 .

30. Blau, Blooded Thought: Occasions of Theatre 134.

40. Qtd. in Lehmann, The Postdramatic Theatre 167.

41. Howard Barker, Death, The One and the Art of Theatre (New York: Routledge, 2004) 2.

42. Elinor Fuchs, The Death of Character: Perspectives on Theatre After Modernism (Bloomington: Indiana UP, 1996) 171.

43. Peggy Phelan, Unmarked: The Politics of Performance (New York: Routledge, 1993) 146.

44. Philip Auslander, Liveness: Performance in a Mediatized Culture (New York: Routledge, 1999) 51.

45. Philip Auslander, "Life from Cyberspace or, I was sitting at my computer this guy appeared he thought I was a bot," Performing Arts Journal 70.1 (2002): 17.

46. 21 .

47. Steve Dixon, Digital Performance: A History of New Media in Theater, Dance, Performance Art, and Installation, Leonardo Books (Cambridge: The MIT Press, 2007) 115.

48. Auslander, "Life from Cyberspace or, I was sitting at my computer this guy appeared he thought I was a bot" 21.

49. Lehmann, The Postdramatic Theatre 22.

50. N. Katherine Hayles, How We Became Posthuman: Virtual Bodies in Cybernetics, Literature, and Informatics (Chicago: U of Chicago P, 1999) 3.

51. Ralf Remshardt, "Beyond Performance Studies: Mediated Performance and the Posthuman," Cultura, Lenguaje y Representación/Language, Culture and Representation 1697.7750 (2008): 59. 
52. Lehmann, The Postdramatic Theatre 163.

53. 167. 1996) xiii.

54. Joseph Roach, Cities of the Dead: Circum-Atlantic Performance (New York: Columbia UP,

55. Joseph Roach, It (Ann Arbor: U of Michigan P, 2007) 229.

56. Joseph Roach, ASTR Conference, Boston, MA, 2008. Address.

57. William Gibson's Neuromancer (1984) is perhaps the most well-known and oft-cited of this genre, and it was in this book that he first coined the term "cyberspace" that was to dominate much of the early discourse on virtuality and computer networks.

59. Here, we may briefly note the compelling theory of "performative time" put forward by Tracy Davis at ASTR (2008), which is set in opposition to the more linearly designed "theatrical time," which has a beginning, middle, and end.

59. Alice Rayner, Ghosts: Death's Double and the Phenomena of Theatre (Minneapolis: U of Minnesota P, 2006) 62.

60. Carlson, The Haunted Stage: Theatre as Memory Machine 7.

61. 7 .

62. Andrew Sofer, The Stage Life of Props, Theater: Theory/Text/Performance (Ann Arbor: U of Michigan P, 2003) 20.

63. 25 .

64. 3 .

65. Josette Féral, "Introduction: Towards a Genetic Study of Performance - Take 2," Theatre Research International 33.3 (2008): 229.

66. 229.

67. Jean-Marie Thomaseau, "Towards a Genetic Understanding of Non-Contemporary Theater: Traces, Object, Methods," Theatre Research International 33.3 (2008): 236.

68. 246.

69. $237,247$.

70. Rayner, Ghosts: Death's Double and the Phenomena of Theatre 62.

71. Diana Taylor, The Archive and the Repertoire: Performing Cultural Memory in the Americas (Durham, N.C.: Duke UP, 2003) 168-9.

72. $168-9$.

73. David Román, Performance in America: Contemporary U.S. Culture and the Performing Arts (Durham, N.C.: Duke UP, 2005) 139.

74. W. B. Worthen, “Antigone's Bones,” TDR: The Drama Review 53.3 (2008): 16.

75. Rayner, Ghosts: Death's Double and the Phenomena of Theatre 30.

76. xxxii. 
